\title{
HUBUNGAN ANTARA KETERDEDAHAN TAYANGAN IKLAN KOMERSIAL MAKANAN RINGAN DAN DUKUNGAN SOSIAL DENGAN PERILAKU JAJAN ANAK
}

\section{The Relation between Televison Commercial Snacks Advertisment Exposure and Social Support with Children's Snacking Behavior}

\author{
Tania Linggarsari Dewi ${ }^{1)}$, Ratri Virianita ${ }^{1)}$ \\ ${ }^{1)}$ Departemen Sains Komunikasi dan Pengembangan Masyarakat, Fakultas Ekologi Manusia, \\ Institut Pertanian Bogor, Dramaga Bogor 16680, Indonesia \\ E-mail: taniasarwono@yahoo.co.id; ratru_v@apps.ipb.ac.id
}

\begin{abstract}
The purposes of this research are to describe: children's television snacks advertisment exposure, children's social support in Tanjungsari Village, and to analize the relation between televison commercial snacks advertisment exposure and social support with children's snacking behavior.This research was conducted in Tanjungsari Village, cijeruk Bogor district. Using quantitave method supported by qualitative data. The results showed high exposure of television snacks commercial advertisement on children, and low social support. The results also showed that there is a relation of televison commercial snacks advertisment exposure ( $\mathrm{rs}=0.480 * *, \rho<0.01)$, and social support $(r s=$ $\left.-0.323^{*}, p<0.05\right)$ on snacking behavior
\end{abstract}

Keyword: advertisment exposure, snacking behavior

\begin{abstract}
ABSTRAK
Penelitian ini bertujuan untuk mendeskripsikan: keterdedahan anak usia sekolah dasar pada tayangan iklan komersial makanan ringan di televisi, keadaan dukungan sosial yang dimiliki anak usia sekolah dasar di Desa Tanjungsari, dan menganalisis hubungan keterdedahan anak pada tayangan iklan komersial makanan ringan di televisi dan dukungan sosial dengan perilaku jajan anak usia sekolah dasar. Penelitian ini dilakukan di Desa Tanjungsari, Kecamatan Cijeruk, Kabupaten Bogor. Penelitian ini menggunakan pendekatan kuantitatif dan didukung oleh data kualitatif. Hasil penelitian menunjukkan keterdedahan anak terhadap tayangan iklan komersial makanan ringan tergolong tinggi, dan dukungan sosial yang dimiliki anak tergolong rendah. Hasil penelitian menunjukkan bahwa terdapat hubungan antara keterdedahan tayangan iklan komersial makanan ringan $(\mathrm{rs}=0.480 * *, \rho<0.01)$, dan dukungan sosial $\left(r s=-0.323^{*}, p<0.05\right)$ dengan perilaku jajan anak.
\end{abstract}

Kata kunci : keterdedahan iklan, perilaku jajan

\section{PENDAHULUAN}

Anak usia sekolah dasar adalah anak yang berusia 6-12 tahun. Pada awal usia 6 tahun anak mulai masuk sekolah. Anak-anak ini masuk ke dalam dunia baru, mereka mulai banyak berhubungan dengan orang-orang di luar keluarganya, dan berkenalan pula dengan suasana dan lingkungan baru dalam kehidupannya (Setiawan 2010). Pada taraf ini anak dalam kondisi peka terhadap stimulus sehingga mudah dibimbing, diarahkan dan ditanamkan kebiasaan-kebiasaan baik (Notoatmodjo 2005).

Anak-anak usia sekolah dasar pada umumnya sudah dapat memilih dan menentukan hal yang disukai dan yang tidak disukai, termasuk makanan. Anak-anak mempunyai sifat yang berubah-ubah terhadap makanan. Seringkali anak memilih makanan yang salah, terlebih lagi jika 
orangtuanya tidak memberikan petunjuk kepada anak. Selain itu anak-anak lebih banyak menghabiskan waktu di luar rumah, sehingga lebih mudah menjumpai aneka bentuk dan jenis makanan jajanan, baik yang dijual di sekitar sekolah, lingkungan bermain ataupun pemberian teman. Anak usia sekolah dasar selalu ingin mencoba makanan yang baru dikenalnya (Moehji1986), karena hal ini anak sekolah tidak dapat terlepas dari perilaku jajan. Perilaku jajan anak yang berlebihan dapat menjadi masalah karena anak menjadi terbiasa mengkonsumsi makanan dengan nutrisi yang buruk.

Seringnya anak mengkonsumsi makanan dengan nutrisi buruk menyebabkan anak mengalami gizi buruk. Terhadap perkembangan anak, dampak jangka pendek gizi buruk terhadap perkembangan anak menurut Nency \& Arifin (2005), diantaranya menjadikan anak apatis, gangguan bicara dan gangguan perkembangan yang lain. Dampak jangka panjang adalah penurunan skor intelligence quotient (IQ), penurunan perkembangan kognitif, penurunan integrasi sensori, gangguan pemusatan perhatian, gangguan penurunan rasa percaya diri dan tentu saja merosotnya prestasi akademik di sekolah. Kurang gizi berpotensi menjadi penyebab kemiskinan melalui rendahnya kualitas sumber daya manusia dan produktivitas. Tidak heran jika gizi buruk yang tidak dikelola dengan baik, pada fase akutnya akan mengancam jiwa dan pada jangka panjang akan menjadi ancaman hilangnya sebuah generasi penerus bangsa

Banyak faktor yang dapat menjadi pemicu perilaku jajan pada anak menjadi berlebihan. Berdasarkan penelitian Eunike (2009), orang tua memiliki peran yang cukup penting dalam menentukan perilaku jajan anak karena dari orang tua anak mendapatkan persetujuan dan uang saku. Selain dukungan sosial instumental berupa uang jajan, iklan perdagangan juga dapat mempengaruhi perilaku jajan anak. Menurut Berg (1985) dalam Berg (1987), pengaruh lain terhadap konsumsi makanan ialah komunikasi massa, terutama iklan perdagangan dan promosi penjualan. Pemberitaan mengenai makanan jajanan yang beredar di televisi pada masa kini memang sudah banyak sehingga amak dapat dengan mudah mengakses berita tersebut dan menyerap isi pesan pemberitaan tersebut.

Hasil penelitian yang dilakukan Ardianto (2001) menyatakan bahwa tayangan anak-anak menempati urutan kedua yang paling sering ditonton yaitu sebesar $74 \%$. Tayangan anak-anak paling banyak disaksikan oleh anak-anak sendiri, sedangkan sebanyak hampir $70 \%$ iklan yang ditampilkan pada tayangan anak-anak adalah makanan ringan atau makanan siap saji. Hal ini dapat menyebabkan perilaku jajan anak yang tidak terkontrol dan berlebihan.

Banyak perusahaan yang mempromosikan produk mereka melalui iklan televisi yang sasarannya adalah anak-anak usia sekolah dasar, seperti iklan mainan barbie, mobil-mobilan, makanan ringan dalam kemasan, minuman rasa buah dan masih banyak iklan lainnya. Anak sekolah merupakan kelompok yang sangat peka untuk menerima perubahan, karena kelompok anak sekolah sedang berada dalam taraf pertumbuhan dan perkembangan. Pada taraf ini anak dalam kondisi peka terhadap stimulus sehingga mudah dibimbing, diarahkan dan ditanamkan kebiasaan-kebiasaan yang baik (Notoatmodjo 2005), karena inilah maka anakanak merupakan kelompok yang sangat mudah dipersuasi dibandingkan orang dewasa.

Kebanyakan tema atau pendekatan yang digunakan untuk menarik perhatian anak-anak adalah menampilkan produk yang berkaitan dengan bermain dan bergembira, informasi yang penting terkait dengan produk yang dijual tidak ditampilkan. Para pengiklan lebih sering memperlihatkan wajah gembira, memunculkan karakter binatang, hal ini memungkinan ketertarikan anak-anak pada produk yang diiklankan menjadi lebih tinggi dalam waktu singkat. Penelitian Lestari (1996) di Bogor mendapati anak-anak yang mengalami kegendutan atau obesistas menonton TV selama 4,5 jam/hari dan anak yang tidak mengalami kegendutan menonton TV selama 3,13 jam/hari. Padahal idealnya tidak lebih dari 2 jam/hari.

Hal yang perlu diperhatikan mengingat adanya televisi di Indonesia saat ini tidak hanya mencakup wilayah perkotaan tetapi juga pedesaan. Masyarakat desa yang cenderung 
berpola pikir sederhana akan lebih mudah terpengaruh dan terdedah oleh tayangan iklan. Pendapat ini didukung oleh Bungin (2008) yang menyatakan masyarakat pedesaan yang sebagian besar bermata pencaharian sebagai petani umumnya memiliki waktu yang cukup banyak di rumah, karena waktu kerja mereka ditentukan sendiri oleh mereka. Hal tersebut menunjukan bahwa potensi keterdedahan masyarakat pedesaan terhadap siaran televisi cukup besar, termasuk keterdedahan terhadap tayangan iklan.

Anak-anak di desa dengan karakteristik seperti di atas menjadi sangat rentan terhadap iklan yang disajikan di televisi. Selain itu ketersediaan sarana hiburan di perkotaan sangat beragam tidak hanya dari televisi. Mall, dan tempat rekreasi juga merupakan sarana hiburan yang bisa didapatkan di perkotaan. Hal tersebut berbeda dengan kondisi di pedesaan, sarana hiburan di desa sebagian besar didapatkan dari tayangan televisi. Berdasarkan data dari Kementerian Komunikasi dan Informatika (2011), tingkat kepemilikan televisi di Indonesia pada tahun 2011 memiliki proporsi mencapai $95.56 \%$ dari jumlah responden, artinya hampir seluruh warga desa memiliki televisi di rumahnya. Dalam penelitiannya, Hadiyanto (2004) menjabarkan bahwa kepemilikan media televisi di desa mencapai $82.5 \%$. Fasilitas sosial yang ada pada desa masih terbatas sehingga sumber hiburan dan informasi di wilayah ini sebagian besar didapat dari televisi. Kondisi ini dapat memunculkan dampak dari tayangan siaran televisi yang salah satu tayangannya adalah iklan komersial makanan ringan di kalangan anak usia sekolah dasar di pedesaan. Oleh karena itu pertanyaan yang akan dibahas dalam penelitian adalah bagaimana hubungan antara tayangan iklan komersial makanan ringan di televisi dan dukungan sosial anak dengan perilaku jajan anak usia sekolah dasar?

Masalah penelitian sebagai berikut:

1. Bagaimana keterdedahan anak usia sekolah dasar terhadap iklan komersial makanan ringan di televisi?

2. Bagaimana dukungan sosial yang dimiliki anak usia sekolah dasar?
3. Bagaimana perilaku jajan anak usia sekolah dasar?

4. Bagaimana hubungan antara keterdedahan tayangan iklan komersial di televisi dan dukungan sosial dengan perilaku jajan anak usia sekolah dasar?

\section{PENDEKATAN TEORITIS}

\section{Perilaku Jajan Anak Usia Sekolah Dasar}

Anak usia sekolah dasar adalah anak yang berusia 6-12 tahun. Menurut Supandi (1992) tingkatan kelas di sekolah dasar dapat dibagi dua menjadi kelas rendah dan kelas atas. Kelas rendah terdiri dari kelas satu, dua, dan tiga, sedangkan kelaskelas tinggi sekolah dasar yang terdiri dari kelas empat, lima, dan enam. Usia siswa pada kelompok kelas atas sekitar 9 sampai 12 tahun. Menurut Witherington (1952) yang dikemukakan Makmun (1995:50) bahwa usia 9-12 tahun memiliki ciri perkembangan sikap individualis sebagai tahap lanjut dari usia 6-9 tahun dengan ciri perkembangan sosial yang pesat. Pada tahapan ini anak/siswa berupaya semakin ingin mengenal siapa dirinya dengan membandingkan dirinya dengan teman sebayanya. Jika proses itu tanpa bimbingan, anak akan cenderung sukar beradaptasi dengan lingkungannya. Untuk itulah sekolah memiliki tanggung jawab untuk menanggulanginya.

\section{Dukungan Sosial}

Saroson dalam Smet (1994) yang menyatakan bahwa dukungan sosial adalah adanya transaksi interpersonal yang ditunjukkan dengan memberikan bantuan pada individu lain, dimana bantuan itu umunya diperoleh dari orang yang berarti bagi individu yang bersangkutan. Dukungan sosial dapat berupa pemberian infomasi, bantuan tingkah laku, ataupun materi yang didapat dari hubungan sosial akrab yang dapat membuat individu merasa diperhatikan, bernilai, dan dicintai. Dukungan sosial menyebabkan individu menyadari bahwa ada orang-orang di sekitarnya yang dapat diandalkan untuk membantu mengatasi tekanan hidupnya, sehingga harga dirinyapun meningkat (Astuti 1998).

Dukungan sosial terdiri atas dukungan instrumental, dukungan informasi, dukungan 
emosi, dan dukungan penghargaan (Sarafino 1990 dalam Hanggarawati 2007). Dukungan instrumental merupakan dukungan dalam bentuk uang, barang, makanan, dan pelayanan. Dukungan informasi mencakup dukungan yang diberikan dalam bentuk informasi dan saran tentang situasi atau kondisi. Dukungan emosi ialah dukungan dalam bentuk rasa sayang, perhatian, kehangatan, dan penerimaan secara apa adanya. Adapun dukungan penghargaan merupakan dukungan yang diberikan dalam bentuk penghargaan positif, pemberian semangat, persetujuan pendapat, dan perbandingan positif dengan orang lain.

\section{Dampak Iklan Televisi}

Komunikasi massa adalah komunikasi yang dilakukan melalui media massa modern, yang meliputi surat kabar yang mempunyai sirkulasi yang luas, siaran radio dan televisi yang ditujukan kepada umum, dan film yang dipertunjukkan di gedung-gedung bioskop (Effendy, 2007). Fungsi Komunikasi Massa menurut Effendy (1993) adalah Fungsi informasi, fungsi pendidikan, fungsi mempengaruhi, dan fungsi menghibur. Salah satu media yang dapat menyampaikan fungsi-fungsi di atas adalah melalui media televisi. Dalam fungsi persuasif selain bisa berfungsi memberikan informasi, iklan juga dapat berfungsi membujuk, merayu konsumen untuk bersikap maupun berprilaku tertentu sesuai yang dikehendaki oleh produsen.

Komunikasi massa memiliki enam teori yaitu teori peluru atau jarum hipodermik, teori komunikasi banyak tahap, teori proses selektif, teori pembelajaran sosial, teori difusi inovasi dan teori kultivasi (Ardianto dkk 2007). Teori yang dapat menjelaskan dampak tayangan iklan di televisi adalah teori pembelajaran sosial. Teori pembelajaran sosial diaplikasikan pada perilaku konsumen. Berdasarkan penelitian Albert Bandura, teori menjelaskan bahwa pemirsa meniru apa yang mereka lihat di televisi, melalui suatu proses observational learning (pembelajaran hasil pengamatan). Klapper menganggap bahwa "ganjaran" dari karakter TV diterima mereka sebagai perilaku antisosial, termasuk menjadi toleran terhadap perilaku perampokan dan kriminalitas, menggandrungi kehidupan glamor seperti di televisi. Teori pembelajaran sosial dapat dipenuhi melalui iklan di televisi.

\section{Keterdedahan Tayangan Iklan Komersial Makanan Ringan di Televisi}

Shore (1990) dikutip oleh Samsi (2005) mendefinisikan keterdedahan adalah kegiatan melihat, membaca, mendengarkan, atau memberikan sejumlah perhatian kepada suatu pesan yang disampaikan dengan menggunakan media sebagai perantaranya. Hasil penelitian Asmira (2006) menunjukkan faktor-faktor lainnya yang mempengaruhi keterdedahan adalah pendidikan, pendapatan, jenis kelamin, jenis pekerjaan, dan status perwakinan. Khalayak dengan pendidikan tinggi cenderung untuk mengurangi keterdedahan terhadap tayangan iklan.

Makanan ringan atau dikenal dengan sebutan snack food adalah makanan yang dikonsumsi selain atau antara waktu makan utama dalam sehari. Oleh karena itu, makanan ini biasa disebut snack yang berarti sesuatu yang dapat mengobati rasa lapar dan memberikan suplai energi yang cukup untuk tubuh (Anonim, 2007). Makanan ringan yang dimaksudkan adalah untuk menghilangkan rasa lapar seseorang sementara waktu dan dapat memberi sedikit suplai energi ke tubuh atau merupakan sesuatu yang dimakan untuk dinikmati rasanya. Kebiasaan mengkonsumsi cemilan ketika jam makan tiba, tak akan menyehatkan tubuh karena kandungan gizi pada makanan ringan tak cukup untuk menutupi kebutuhan asupan nutrisi tubuh anda. Makanan ringan tak cukup mengandung karbohidrat yang berfungsi sebagai energi dan kekuatan.

Dalam makanan ringan pada umumnya juga ditambahkan bahan-bahan lain misalnya monosodium glutamat (MSG) sebagai penyedap, bahan pengawet, bahan pewarna, bahan pemanis dan juga ditambahkan bahan anti pengempal yang biasanya ditambahkan pada minuman serbuk, dan bumbu snack. Bahan-bahan tersebut bila ditambahkan sesuai takaran yang disarankan tidak menjadi masalah tetapi bila diberikan tidak sesuai aturan, hal tersebut dapat membahayakan kesehatan. 


\section{Kerangka Pemikiran}

Perilaku jajan anak merupakan perilaku konsumen anak usia sekolah dasar yaitu 6-12 tahun. Perilaku jajan anak usia sekolah dasar yang tinggi disebabkan beberapa faktor, diduga salah satunya adalah keterdedahan terhadap media massa. Salah satu media massa yang memiliki pengaruh kuat bagi khalayak adalah televisi. Iklan di televisi bisa menjadi sarana bagi khalayak untuk mendapatkan informasi mengenai produk, seperti harga dan keunggulan produk, dan juga sebagai sarana hiburan untuk khalayak. Teori pembelajaran sosial dapat diaplikasikan pada perilaku anak dalam berjajan, anak meniru apa yang mereka lihat di televisi, melalui suatu proses observational learning (pembelajaran hasil pengamatan), dalam hal ini pengamatan anak pada iklan makanan ringan. Dampak iklan televisi di kalangan khalayak muncul sebagai akibat keterdedahan khalayak terhadap iklan. Keterdedahan terhadap tayangan iklan dikaji dengan menggunakan variabel-variabel, seperti: durasi, frekuensi, dan jenis iklan yang sering ditonton.

Dukungan sosial yang merupakan suatu bentuk dukungan dari orang di luar individu, dapat memberikan sumbangan. Menurut Notoatmodjo (2003) perilaku jajan anak dapat dipengaruhi oleh lingkungan keluarga (orang tua), teman sebaya, media massa dan sebagainya. Keluarga dan teman sebaya dapat memberikan dukungan sosial, yang berupa dukungan instrumental berupa uang jajan, dan dukungan informasi. Dukungan instrumental dari orang tua dapat berpengaruh pada perilaku jajan anak karena orang tua yang memberikan uang jajan kepada anak. Suci (2009) menyatakan orang tua merupakan salah satu faktor penentu perilaku jajan anak sekolah dasar karena dari orangtua lah anak mendapat uang saku. Teman sebaya dapat mempengaruhi perilaku jajan anak karena anak cenderung mengikuti kebiasaan teman sepermainannya agar anak merasa nyaman pada suatu lingkungan. Menurut Perdana (2014) Informasi yang diberikan oleh teman sebaya juga dianggap sebagai salah satu bentuk dukungan informasi yang positif sehingga akan mempengaruhi seseorang dalam berperilaku.

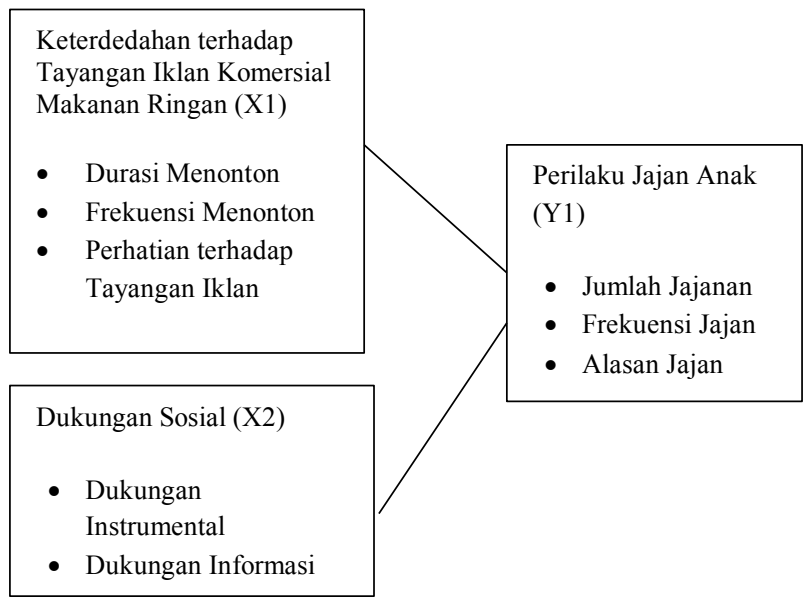

Keterangan: $\quad$ : berhubungan

Gambar 1 Kerangka pemikiran hubungan antara keterdedahan terhadap tayangan iklan komersial makanan ringan dan dukungan sosial dengan perilaku jajan anak.

\section{Hipotesis Penelitian}

Hipotesis penelitian adalah sebagai berikut

1. Diduga terdapat hubungan positif antara keterdedahan terhadap iklan komersial makanan ringan di televisi (durasi, frekuensi menonton dan perhatian pada tayangan iklan) dengan perilaku jajan anak.

2. Diduga terdapat hubungan negatif antara dukungan sosial yang dimiliki anak (dukungan instrumental, dan dukungan informasi) dengan perilaku jajan anak usia sekolah dasar

\section{PENDEKATAN LAPANG}

Penelitian ini menggunakan pendekatan kuantitatif yang didukung data kualitatif. Pendekatan kuantitatif dilakukan dengan metode survei, yaitu dengan menggunakan kuesioner sebagai alat pengumpulan data. Data kualitatif diperoleh melalui wawancara mendalam terhadap informan.

Penelitian ini dilaksanakan di Desa Tanjungsari, Kecamatan Cijeruk, Kabupaten Bogor. Pemilihan lokasi ini dilakukan secara sengaja (purposive). Desa ini termasuk desa yang sulit dijangkau 
karena tidak ada transportasi umum. Lokasi tersebut dipilih dengan pertimbangan sebagian besar masyarakat desa tersebut telah memiliki televisi, sehingga akses terhadap tayangan iklan televisi mudah dan masyarakat berpotensi terdedah tayangan iklan komersial di televisi. Selain itu akses kendaraan umum di Desa Tanjungsari sangat terbatas, sehingga masyarakat lebih memilih menghabiskan waktu dirumah dibanding berpergian. Sebelum melakukan penelitian, penulis melakukan survei langsung ke lokasi penelitian, wawancara dengan narasumber terkait seperti aparat desa, beberapa guru dan anak-anak, serta penelusuran kepustakaan dari beberapa penelitian sebelumnya.

Penelitian dilaksanakan dalam waktu 5 bulan, dimulai dari bulan Januari. Kegiatan penelitian dimulai dari penjajagan lokasi penelitian, penyusunan proposal penelitian, kolokium, pengambilan data di lapang, penyusunan draft skripsi, sidang skripsi, dan perbaikan laporan skripsi

Populasi penelitian ini adalah seluruh anak usia sekolah dasar antara 10-12 tahun yang berada pada tingkatan kelas 4,5 , dan 6 SD yang bersekolah di SDN Tajurhalang 01 dan 04, serta yang menonton televisi di desa Tanjungsari berjumlah 227. Penelitian ini melibatkan responden dan informan sebagai perolehan data primer di lapangan. Responden adalah pihakpihak yang dijadikan sebagai sampel dalam penelitian, sebanyak 40 anak dengan pembagian 30 anak dari SDN Tajurhalang 04 dan 10 anak dari SDN 01 Tajurhalang. Pemilihan responden menggunakan teknik pengambilan sampel acak sederhana, hal ini dilakukan untuk menghindari subjektifitas, dan setiap unsur dalam populasi memiliki kesempatan yang sama untuk dipilih sebagai sampel, karena populasi di desa pernah menonton iklan televisi, sehingga responden yang dipilih secara acak cukup mewakili dari populasi.

Informan adalah orang yang dapat memberikan informasi dan data relevan untuk mendukung penelitian ini. Informan dipilih secara sengaja yang merupakan orang tua dan para guru dari responden, serta pihak-pihak terkait. Unit analisis pada penelitian ini adalah individu.
Data yang dibutuhkan dalam penelitian ini meliputi data primer dan data sekunder. Data primer, yaitu data yang diperoleh langsung di lapangan dari responden melalui kuesioner. Wawancara mendalam kepada informan desa Tanjungsari, yang dipilih secara sengaja.

Kuesioner diuji coba kepada 10 responden yang dipilih secara sengaja dan diluar dari responden penelitian sebenarnya, untuk menguji validitas dan reliabilitas kuesioner dimana kuesioner merupakan instrumen pengumpulan data kuantitatif. Validitas merupakan alat pengukur untuk mengukur apa yang ingin diteliti sementara reliabilitas merupakan sejauhmana hasil pengukuran relatif konsisten apabila pengukuran diulangi sebanyak dua kali atau lebih (Singarimbun 2006). Data sekunder dalam penelitian ini diperoleh dari hasil studi sebelumnya mengenai pengaruh tayangan iklan seperti jurnal penelitian, skripsi, dan thesis.

Uji reliabilitas terhadap kuesioner sebagai instrumen pengumpulan data menghasilkan Cronbach's Alpha, sebagai berikut: 1) variabel keterdedahan anak terhadap tayangan iklan makanan ringan $(\alpha=0,90), 2)$ variabel dukungan sosial $(\alpha=0.706)$, dan 3$)$ variabel perilaku jajan anak $(\alpha=0.777)$. Adapun uji validitas menggunakan metode corrected item-total correlation dengan nilai $\mathrm{r}$-tabel $=0.632$, dan masing-masing item dinyatakan valid karena nilai r-hitung $>$ r-tabel.

Penelitian ini memiliki dua jenis data yang diolah dan dianalisis, yaitu data kuantitatif dan data kualitatif. Data kuantitatif yang diperoleh dari kuesioner diolah secara statistik, dibantu oleh program SPSS version 21 for windows. Semua data kuantitatif yang diperoleh pada lembaran kuesioner dimasukan ke dalam program Microsoft Excel 2010 secara lengkap dan diuraikan per variabel. Pengolahan dan analisis data menggunakan uji korelasi rank spearman dan chi square, tujuan dari penggunaan analisis korelasi rank spearman adalah untuk menguji hipotesis, yaitu hubungan antara keterdedahan tayangan iklan komersial makanan ringan dan dukungan sosial anak dengan perilaku jajan anak usia sekolah dasar, sedangkan penggunaan chi square adalah untuk mengetahui faktor lain yang berhubungan dengan perilaku jajan anak. 


\section{HASIL DAN PEMBAHASAN}

\section{Gambaran Umum Lokasi Penelitian}

SDN Tajurhalang 04 berada di Jalan Tanjungsari RT 02, RW 01, Desa Tanjungsari, Kecamatan Cijeruk, Kabupaten Bogor. Terdapat enam ruang kelas dengan total 341 siswa dan jumlah pengajar sebanyak lima belas orang. Fasilitas sekolah ini adalah SDN Tajurhalang 04 memiliki satu warung jajan di halaman sekolah. Jenis makanan jajanan yang disediakan di warung tersebut adalah makanan dan minuman dalam kemasan dan merupakan produk-produk yang sering disiarkan di televisi. Selain makanan jajanan yang dijual di warung sekolah, murid-murid di sekolah ini juga dapat membeli makanan ringan yang dijajakan oleh pedagang asongan di dalam maupun di luar sekolah.

SDN Tajurhalang 01 berada di pada jalan Tanjungsari no 1, kampung Palasari, RT 02/RW 01 Desa Tanjungsari, Kecamatan Cijeruk, Kabupaten Bogor.. Berbeda dengan SDN Tajurhalang 04, SD ini memiliki ruang kelas yang lebih sedikit yaitu hanya tiga kelas dengan total 153 siswa, dan jumlah pengajar nya enam orang. Fasilitas sekolah ini adalah SDN Tajurhalang 01 memiliki satu warung jajan dibelakang sekolah yang dikelola oleh salah satu guru dari SDN Tajurhalang 01. Jenis makanan jajanan yang disediakan di warung tersebut adalah makanan dan minuman olahan dari guru yang berjualan, seperti sosis dan bakso, tetapi ada beberapa jajanan seperti makanan dan minuman dalam kemasan. Selain makanan jajanan yang dijual di warung sekolah, murid-murid di sekolah ini juga dapat membeli makanan ringan yang dijajakan oleh pedagang asongan diluar sekolah.

\section{Gambaran Keterdedahan Tayangan Iklan Makanan Ringan di Televisi pada Anak}

Keterdedahan tayangan iklan komersial televisi adalah suatu proses kegiatan melihat, membaca, mendengarkan, atau memberikan sejumlah perhatian pada media televisi, untuk mencari pesan sehingga dapat menentukan sikap atau perilaku kepada promosi suatu produk di media televisi. Keterdedahan pada penelitian diukur dari frekuensi menonton, durasi menonton, dan perhatian pada tayangan iklan makanan ringan. Keterdedahan terhadap tayangan televisi disajikan dalam tabel 1 .
Tabel 1 Jumlah dan persentase keterdedahan tayangan iklan makanan ringan pada responden

\begin{tabular}{lcc}
\hline $\begin{array}{c}\text { Keterdedahan tayangan } \\
\text { iklan makanan ringan pada } \\
\text { anak }\end{array}$ & $\begin{array}{c}\text { Jumlah } \\
\text { (n) }\end{array}$ & $\begin{array}{c}\text { Persentase } \\
(\%)\end{array}$ \\
\hline Rendah & 0 & 0 \\
Sedang & 28 & 70 \\
Tinggi & 12 & 30 \\
\hline Total & 40 & 100 \\
\hline
\end{tabular}

Dari Tabel 1. diketahui keterdedahan anak pada tayangan iklan makanan ringan yang tergolong sedang sebanyak $70 \%$ atau 28 responden, dan sisanya sebanyak $30 \%$ responden tergolong tinggi. Data tersebut didapat dari pengkategorian kembali jumlah dari frekuensi anak menonton, durasi menonton, dan perhatian anak terhadap tayangan iklan makanan ringan. Dalam penelitian ini tidak ada responden dengan keterdedahan tayangan iklan makanan ringan tergolong rendah.

\section{Gambaran Dukungan Sosial Anak}

Dukungan sosial anak merupakan bantuan yang berasal dari orang lain seperti, orang tua, teman sebaya yang dapat membantu responden dalam menyelsaikan masalahnya. Dukungan sosial yang digunakan pada penelitian ini adalah dukungan instrumental berupa pemberian uang jajan pada responden dari orang tuanya, dan dukungan informasi yang berupa berita-berita dan informasi tentang makanan ringan dan persetujuan pembelian makanan ringan dari orang-orang disekeliling responden yaitu teman-teman sebayanya. Dukungan sosial dinilai berdasarkan hal-hal yang bersangkutan dengan perilaku jajan yang dirasakan oleh anak. Untuk mengetahuinya, dukungan sosial didapat dari gabungan antara dukungan instrumental dan dukungan informasi. Berikut jumlah dan presentase dukungan sosial responden.

Tabel 2. Jumlah dan persentase dukungan sosial responden

\begin{tabular}{lcc}
\hline $\begin{array}{c}\text { Dukungan } \\
\text { sosial }\end{array}$ & Jumlah (n) & $\begin{array}{c}\text { Persentase } \\
(\mathbf{\%})\end{array}$ \\
\hline Rendah & 23 & 57,5 \\
Sedang & 17 & 42,5 \\
Tinggi & 0 & 0 \\
\hline Total & $\mathbf{4 0}$ & $\mathbf{1 0 0}$ \\
\hline
\end{tabular}


Berdasarkan Tabel 2, data yang diperoleh dari kuisioner, didapat tingkatan dukungan sosial yang dimiliki sebagian besar anak adalah rendah. Lebih dari 50\% anak memiliki dukungan sosial rendah, yang merupakan hasil dari dukungan instrumental dan dukungan sosial yang dimiliki anak.

"Saya ngasih jajan yang pastinya setiap hari sebelum pada berangkat sekolah tuh, nanti siang pas mau ngaji biasanya saya kasih lagi, terus sekali-kali ada sih kalo anak mau main kan suka disamper tuh sama temen-temennya, abisnya kasian mba kalo dia ngga dikasih jajan nanti dia melongo, temennya pada makan" ( Ibu ID, 38 tahun)

\section{Hubungan antara Keterdedahan Tayangan Iklan Komersial Makanan Ringan dan Dukungan Sosial dengan Perilaku Jajan Anak}

\section{Hubungan Keterdedahan Tayangan Iklan Komersial Makanan Ringan dan Perilaku Jajan Responden}

Berdasarkan Tabel 3, dapat dikatakan bahwa perilaku jajan anak dominan tinggi baik pada keterdedahan anak pada tayangan iklan komersial makanan ringan yang sedang maupun tinggi yaitu sebanyak 28 responden. Nilai korelasi antara variabel keterdedahan tayangan iklan makanan ringan dengan perilaku jajan sebesar $0.480^{* *}$, nilai tersebut menunjukkan hubungan kedua variabel tersebut merupakan hubungan sedang. Didapat nilai signifikan hitung sebesar $(\mathrm{p}=0,002<0,01)$.

Hasil tersebut menunjukkan hubungan antar dua variabel tersebut signifikan. Sesuai dengan hasil penelitian yang telah dilakukan Fitriyah (2013) hal yang memicu anak dalam pembelian makanan ringan adalah tingginya intensitas anak dalam menonton televisi.
Tabel 3 Hubungan antara keterdedahan tayangan iklan komersial makanan ringan dan perilaku jajan responden

\begin{tabular}{|c|c|c|c|c|c|c|c|c|}
\hline \multirow{3}{*}{$\begin{array}{l}\text { Keterdedahan } \\
\text { tayangan iklan } \\
\text { komersial } \\
\text { makanan ringan } \\
\text { pada anak } \\
\end{array}$} & \multicolumn{6}{|c|}{ Perilaku jajan responden } & \multirow{2}{*}{\multicolumn{2}{|c|}{ Total }} \\
\hline & \multicolumn{2}{|c|}{ Rendah } & \multicolumn{2}{|c|}{ Sedang } & \multicolumn{2}{|c|}{ Tinggi } & & \\
\hline & (n) & $\%$ & (n) & $(\%)$ & (n) & $(\%)$ & (n) & $(\%)$ \\
\hline Rendah & 0 & 0 & 0 & 0 & 0 & 0 & 0 & 0 \\
\hline Sedang & 0 & 0 & 14 & 35 & 14 & 35 & 28 & 70 \\
\hline Tinggi & 0 & 0 & 0 & 0 & 12 & 30 & 12 & 30 \\
\hline Total & 0 & 0 & 14 & 35 & 26 & 65 & 40 & 100 \\
\hline
\end{tabular}

\section{Hubungan antara frekuensi menonton dengan perilaku jajan responden}

Berdasarkan Tabel 4, terlihat bahwa perilaku jajan anak dominan tinggi baik pada frekuensi menonton yang sedang maupun tinggi. Hal ini terlihat bahwa seringnya anak menonton televisi tidak mempengaruhi perilaku jajan mereka. Diperoleh nilai korelasi antara variabel frekuensi menonton dengan perilaku jajan sebesar 0.278. Nilai signifikan hitung sebesar $(\mathrm{p}=0,082>0,05)$.

Tabel 4 Hubungan antara frekuensi menonton dengan perilaku jajan anak

\begin{tabular}{cccccccccc}
\hline Frekuensi & \multicolumn{4}{c}{ Perilaku jajan responden } & \multirow{2}{*}{ Total } \\
\cline { 2 - 8 } $\begin{array}{c}\text { menonton } \\
\text { responden }\end{array}$ & \multicolumn{2}{c}{ Rendah } & \multicolumn{2}{c}{ Sedang } & \multicolumn{2}{c}{ Tinggi } & \multicolumn{2}{c}{} \\
\cline { 2 - 8 } & $(\mathrm{n})$ & $\%$ & $(\mathrm{n})$ & $(\%)$ & $(\mathrm{n})$ & $(\%)$ & $(\mathrm{n})$ & $(\%)$ \\
\hline Rendah & 0 & 0 & 0 & 0 & 0 & 0 & 0 & 0 \\
Sedang & 0 & 0 & 11 & 27,5 & 13 & 32,5 & 24 & 60 \\
Tinggi & 0 & 0 & 3 & 7,5 & 13 & 32,5 & 16 & 40 \\
\hline Total & 0 & 0 & 14 & 35 & 26 & 65 & 40 & 100 \\
\hline
\end{tabular}

Ket: $\rho>0.05 \quad$ rs $=0.278$

Hasil tersebut menunjukkan hubungan antar dua variabel tersebut tidak signifikan Berbeda dengan hasil penelitian yang dilakukan Sutisna (2000) yang menyatakan bahwa frekuensi menonton tayangan iklan berhubungan nyata dengan pembelian suatu produk.

\footnotetext{
"Aku kalau nonton sering teh, pagi mau berangkat, pulang sekolah, sore pas mau magrib habis main, terus malem kalau udah ngerjain pr sampe ngantuk aku nontonnya, kalo iklan makanan ringan paling ada sih aku liat banyak tiga atau empat iklan, banyaknya mah iklan sabun, atau iklan sinetron lain" (NH, 11 tahun)
} 


\section{Hubungan antara durasi menonton dengan perilaku jajan anak}

Berdasarkan Tabel 5, terlihat bahwa perilaku jajan anak dominan tinggi baik pada durasi menonton yang sedang yaitu sebesar 37,5\%. Diperoleh nilai korelasi antara variabel frekuensi menonton dengan perilaku jajan sebesar 0.064 . Nilai signifikan hitung sebesar $(p=0,694>0,05)$. Hasil tersebut menunjukkan hubungan antar dua variabel tersebut tidak signifikan.

Tabel 5 Hubungan antara durasi menonton dengan perilaku jajan anak

\begin{tabular}{|c|c|c|c|c|c|c|c|c|}
\hline \multirow{3}{*}{$\begin{array}{c}\text { Durasi } \\
\text { Menonton }\end{array}$} & \multicolumn{6}{|c|}{ Perilaku jajan responden } & \multirow{2}{*}{\multicolumn{2}{|c|}{ Total }} \\
\hline & \multicolumn{2}{|c|}{ Rendah } & \multicolumn{2}{|c|}{ Sedang } & \multicolumn{2}{|c|}{ Tinggi } & & \\
\hline & $(\mathrm{n})$ & $\%$ & $(\mathrm{n})$ & $(\%)$ & $(\mathrm{n})$ & $(\%)$ & $(\mathrm{n})$ & $(\%)$ \\
\hline Rendah & 0 & 0 & 0 & 0 & 0 & 0 & 0 & 0 \\
\hline Sedang & 0 & 0 & 9 & 22,5 & 15 & 37,5 & 24 & 60 \\
\hline Tinggi & 0 & 0 & 5 & 12,5 & 11 & 27,5 & 16 & 40 \\
\hline Total & 0 & 0 & 14 & 35 & 26 & 65 & 40 & 100 \\
\hline
\end{tabular}

Ket: $\rho>0.05 \quad$ rs $=0.064$

"Ih neng anak saya mah hese kalo disuruh belajar teh ya, namanya ge anak lalaki sok bandel, kalo udah nonton nepikeun dicarekan heula lamun itu teh. Komo deui lamun geus weungi mah meni lama nepikeun jam 10 mah aya neng, ibu mah teu kabagean nonton teh, hese deuh" (Ibu MM, 42 tahun)

4. Hubungan antara perhatian pada tayangan iklan komersial makanan ringan dengan perilaku jajan anak

Berdasarkan Tabel 6, terlihat bahwa perilaku jajan anak dominan tinggi baik pada perhatian pada tayangan iklan yang tergolong tinggi, yaitu sebesar 47,5\%. Didapat nilai signifikan hitung sebesar $\quad(p=0,006<0,01)$. Hasil tersebut menunjukkan hubungan antar dua variabel tersebut signifikan. Hasil uji korelasi Rank Spearman diperoleh nilai korelasi antara variabel frekuensi menonton dengan perilaku jajan sebesar $0.429 * *$. Nilai tersebut menunjukkan hubungan kedua variabel tersebut merupakan hubungan yang tergolong sedang. Sama halnya dengan hasil penelitian yang dilakukan Fitriyah (2013) yang menyatakan bahwa hal-hal yang menarik perhatian responden dalam menonton tayangan iklan adalah model iklan dan slogan yang digunakan. "aku ngga suka ngeganti-ganti film teh, soalnya kan kalo nonton sopo jarwo, atau upin, pokoknya apa aja deh kan iklannya sedikit, jadi nanti takut keburu mulai teh, jadinya ngga pernah aku ganti. Pernah waktu itu aku berantem sama kakak aku gara-gara dia suka ngeganti film kalo lagi iklan. Lagian iklannya juga seru teh ngga ngebosenin, aku suka iklan minuman" (DS 12 tahun)

Tabel 6 Hubungan perhatian pada tayangan iklan komersial makanan ringan dengan perilaku jajan anak

\begin{tabular}{|c|c|c|c|c|c|c|c|c|}
\hline \multirow{3}{*}{$\begin{array}{c}\text { Perhatian pada } \\
\text { tayangan iklan } \\
\text { komersial } \\
\text { makanan ringan }\end{array}$} & \multicolumn{6}{|c|}{ Perilaku jajan responden } & \multirow{2}{*}{\multicolumn{2}{|c|}{ Total }} \\
\hline & \multicolumn{2}{|c|}{ Rendah } & \multicolumn{2}{|c|}{ Sedang } & \multicolumn{2}{|c|}{ Tinggi } & & \\
\hline & $\mathrm{n}$ & $\%$ & $\mathrm{n}$ & $\%$ & $\mathrm{n}$ & $\%$ & $\mathrm{n}$ & $\%$ \\
\hline Rendah & 0 & 0 & 0 & 0 & 0 & 0 & 0 & 0 \\
\hline Sedang & 0 & 0 & 10 & 25 & 7 & 17,5 & 17 & 42,5 \\
\hline Tinggi & 0 & 0 & 4 & 10 & 19 & 47,5 & 23 & 57,5 \\
\hline Total & 0 & 0 & 14 & 35 & 26 & 65 & 40 & 100 \\
\hline
\end{tabular}

\section{Hubungan antara Dukungan Sosial dengan Perilaku Jajan Anak}

Berdasarkan Tabel 7, dapat dikatakan bahwa perilaku jajan anak dominan tinggi pada dukungan sosial yang rendah yaitu sebanyak $45 \%$ responden. Didapat hasil uji korelasi antara variabel dukungan sosial dengan perilaku jajan anak sebesar -0.323 . Nilai tersebut menunjukkan hubungan kedua variabel merupakan hubungan rendah. Dapat dilihat juga nilai signifikan hitung sebesar $0.042<p(0.05)$.

Tabel 7 Hubungan antara dukungan sosial dan perilaku jajan anak

\begin{tabular}{cccccccccc}
\hline \multirow{2}{*}{$\begin{array}{c}\text { Dukungan } \\
\text { sosial }\end{array}$} & \multicolumn{4}{c}{ Perilaku jajan responden } & \multicolumn{2}{c}{ Total } \\
\cline { 2 - 7 } & \multicolumn{2}{c}{ Rendah } & \multicolumn{3}{c}{ Sedang } & \multicolumn{2}{c}{ Tinggi } & \multicolumn{2}{c}{} \\
\cline { 2 - 7 } Rendah & 0 & 0 & 5 & 12.5 & 18 & 45 & 23 & 57.5 \\
Sedang & 0 & 0 & 9 & 22.5 & 8 & 20 & 17 & 42.5 \\
Tinggi & 0 & 0 & 0 & 0 & 0 & 0 & 0 & 0 \\
\hline Total & 0 & 0 & 14 & 35 & 26 & 65 & 40 & 100 \\
\hline
\end{tabular}

Ket $: p<0.05 r s=-0.323 *$

Hasil tersebut menunjukkan hubungan antar dua variabel tersebut signifikan. Berdasarkan hasil tersebut maka dapat disimpulkan bahwa terdapat hubungan antara keterdedahan tayangan iklan komersial makanan ringan dengan dukungan sosial yang dimiliki anak. Kesimpulan diatas sesuai dengan penelitian Purwaningwulan (2013) 
yang menyatakan hubungan anak dengan orang tua serta proses sosialisasi yang dilakukan oleh anak-anak dapat berdampak pada perilaku konsumtif anak.

\section{Hubungan antara dukungan instrumental dengan perilaku jajan anak}

Berdasarkan Tabel 8 diatas terlihat bahwa perilaku jajan anak tergolong tinggi pada dukungan instrumental yang tergolong rendah yaitu sebanyak $40 \%$. Diperoleh nilai korelasi antara variabel dukungan instrumental dengan perilaku jajan anak sebesar -0.244. Nilai signifikan hitung sebesar $0.129>p(0.05)$.

Tabel 8 Hubungan antara dukungan instrumental dengan perilaku jajan anak

\begin{tabular}{|c|c|c|c|c|c|c|c|c|}
\hline \multirow{3}{*}{$\begin{array}{l}\text { Dukungan } \\
\text { instrumental }\end{array}$} & \multicolumn{6}{|c|}{ Perilaku jajan responden } & \multirow{2}{*}{\multicolumn{2}{|c|}{ Total }} \\
\hline & \multicolumn{2}{|c|}{ Rendah } & \multicolumn{2}{|c|}{ Sedang } & \multicolumn{2}{|c|}{ Tinggi } & & \\
\hline & $(\mathrm{n})$ & $\%$ & (n) & $(\%)$ & (n) & $(\%)$ & $(\mathrm{n})$ & $(\%)$ \\
\hline Rendah & 0 & 0 & 5 & 12,5 & 16 & 40 & 21 & 52,5 \\
\hline Sedang & 0 & 0 & 8 & 20 & 9 & 22,5 & 17 & 42,5 \\
\hline Tinggi & 0 & 0 & 1 & 2,5 & 1 & 2,5 & 2 & 5 \\
\hline Total & 0 & 0 & 14 & 35 & 26 & 65 & 40 & 100 \\
\hline
\end{tabular}

Hasil tersebut menunjukkan hubungan antar dua variabel tersebut tidak signifikan. Berdasarkan hasil tersebut maka dapat disimpulkan bahwa tidak terdapat hubungan antara dukungan instrumental dengan perilaku jajan yang dimiliki anak. Hal ini bertolak belakang dengan penelitian Suci (2009) yang mengatakan bahwa orang tua memberikan pengaruh pada perilaku jajan anak dalam hal pemberian uang saku pada anak.

\begin{abstract}
"Dari pada anak kita jajan ngga bener ya kan teh, jajan cilor, jajan martabak martabak gitu kan bahaya belom minyaknya sama mecinnya kan saya khawatir, mending saya beliin langsung tuh makanan yang mall mall, kaya yang di superindo ada dirumah komplit, kan anak mah suka pengaruh temennya ya teh" (Ibu NS, 45 tahun)
\end{abstract}

\section{Hubungan antara dukungan informasi dengan perilaku jajan anak}

Terlihat pada tabel diatas perilaku jajan anak dominan tinggi pada dukungan informasi responden yang tergolong rendah. Nilai korelasi antara variabel dukungan informasi dengan perilaku jajan anak sebesar 0,077 . Nilai signifikan hitung sebesar $0.642>p(0.05)$. Hasil tersebut menunjukkan hubungan antar dua variabel tersebut tidak signifikan. Berdasarkan hasil tersebut maka dapat disimpulkan bahwa tidak terdapat hubungan antara dukungan informasi dengan perilaku jajan yang dimiliki anak. Hal ini sesuai dengan penelitian yang dilakukan oleh Safriana (2012) yang menyatakan bahwa teman tidak menunjukkan perbedaan proporsi dengan perilaku jajan.

Tabel 9 Hubungan antara dukungan informasi dengan perilaku jajan anak

\begin{tabular}{|c|c|c|c|c|c|c|c|c|}
\hline \multirow{3}{*}{$\begin{array}{l}\text { Dukungan } \\
\text { informasi }\end{array}$} & \multicolumn{6}{|c|}{ Perilaku jajan responden } & \multirow{2}{*}{\multicolumn{2}{|c|}{ Total }} \\
\hline & \multicolumn{2}{|c|}{ Rendah } & \multicolumn{2}{|c|}{ Sedang } & \multicolumn{2}{|c|}{ Tinggi } & & \\
\hline & (n) & $\%$ & (n) & $(\%)$ & (n) & $(\%)$ & (n) & $(\%)$ \\
\hline Rendah & 0 & 0 & 13 & 32,5 & 22 & 55 & 35 & 87,5 \\
\hline Sedang & 0 & 0 & 1 & 2,5 & 4 & 10 & 5 & 12,5 \\
\hline Tinggi & 0 & 0 & 0 & 0 & 0 & 0 & 0 & 0 \\
\hline Total & 0 & 0 & 14 & 35 & 26 & 65 & 40 & 100 \\
\hline
\end{tabular}

\section{SIMPULAN DAN SARAN}

\section{Simpulan}

Keterdedahan sebagian besar anak-anak usia sekolah dasar di Desa Tanjungsari Kabupaten Bogor terhadap televisi tergolong sedang, dan sebagian lainnya tergolong tinggi. Meski keterdedahan sebagian besar anak pada tayangan iklan komersial makanan ringan tergolong sedang, tetapi tidak ada anak dengan keterdedahan tayangan iklan komersial makanan ringan yang tergolong rendah. Sebagian besar anak mengaku tertarik dengan iklan makanan ringan yang ditayangkan setiap kali anak-anak menonton. Mereka menyukai animasi yang ada pada iklan, dan musiknya, sehingga banyak anak yang memperhatikan tayangan iklan makanan ringan setiap kali jeda iklan ketika mereka menonton televisi.

Hasil dari penelitian menunjukkan anak-anak memiliki dukungan sosial yang rendah, didasarkan pada dukungan instrumental dan dukungan informasi yang dimiliki anak. Dukungan instrumental dan dukungan informasi dalam penelitian merupakan hal yang dapat memicu perilaku jajan anak. Sebagian besar anak menerima uang jajan yang cukup banyak dalam sehari dan mereka habiskan untuk membeli makanan ringan. Sama halnya dengan dukungan 
instrumental, dukungan informasi yang dimiliki anak juga rendah, karena anak mendapat banyak informasi tentang makanan ringan baik dari temannya ataupun dari tayangan iklan di televisi.

Banyak anak yang tertarik dengan produk makanan ringan di televisi, sehingga anak sering membeli produk makanan ringan tersebut. Perilaku jajan anak di Desa Tanjungsari tinggi. Tidak dapat dipungkiri anak tidak dapat dipisahkan dari perilaku jajan. Hasil penelitian ini menunjukkan bahwa variabel keterdedahan tayangan iklan makanan ringan berhubungan positif dan signifikan dengan perilaku jajan anak. Variabel dukungan sosial juga menunjukkan adanya hubungan yang negatif dengan perilaku jajan anak di Desa Tanjungsari.

\section{Saran}

Bagi para orang tua sebaiknya lebih megawasi anak dalam menonton tayangan televisi. Hal yang sangat mempengaruhi adalah perhatian anak pada tayangan, sebaiknya ketika anak menonton tayangan televisi harus diawasi, agar anak tidak salah mengartikan iklan yang disaksikan, tidak hanya kegembiaraan yang ditampilkan, anak harus tau dampak negatif dari jajanan yang diiklankan di televisi. Selain itu orang tua harus bisa mengalihkan perhatian anak agar tidak selalu tertuju pada televisi.

Hal lain yang harus diperhatikan oleh orang tua adalah lingkungan bermain anak. Orang tua harus senantiasa mengarahkan anak dalam berperilaku, jangan sampai anak mudah terpengaruh oleh teman-temannya.

Bagi pihak sekolah untuk lebih mengawasi pedagang yang berjualan di sekeliling sekolah, jangan sampai membahayakan siswanya. Alangkah lebih baik saat jam pelajaran berlangsung pagar sekolah ditutup agar siswa tidak bebas keluar masuk halaman sekolah, selain siswa dapat keluar masuk untuk membeli jajanan, resiko kecelakaan anak juga meningkat mengingat anak usia sekolah dasar masih sering berlarian, dan banyak motor yang berlalu-lalang.

Bagi akademisi yang mempunyai ketertarikan dengan penelitian ini, diharapkan melanjutkan penelitian ini dengan jumlah responden yang lebih banyak sehingga dapat memperdalam dan memperkaya hasil dari penelitian ini.

\section{DAFTAR PUSTAKA}

Abdul W. 2015. Konsep Orang Tua Dalam Membangun Kepribadian Anak. Jurnal Paradigma. [Internet[. [Diunduh 4 Desember 2016]. Vol . 2, No. 1. Dapat diunduh di http://ejournal.kopertais4.or.id/index.php/para digma/article/download/898/653

Andika, Jurian. 2008. Hubungan keterdedahan terhadap media massa dengan pengetahuan tentang kebijakan pemerintah mengenai flu burung (Kasus pada mahasiswa fakultas peternakan IPB). [skripsi]. Bogor (ID): Institut Pertanian Bogor.

Anitaliza, 1999. Hubungan Dukungan Sosial dengan Penyesuaian Sosial pada Anak Panti Asuhan di Panti Asuhan Harapan Remaja, Panti Asuhan Ani'mah, dan Panti Asuhan Kampung Melayu Jakarta. Skripsi. Jakarta: Universitas Persada Indonesia Y.A.I

Anitaliza. 1999. Hubungan Dukungan Sosial dengan Penyesuaian Sosial pada Anak Panti Asuhan di Panti Asuhan Harapan Remaja, Panti Asuhan Ani'mah, dan Panti Asuhan Kampung Melayu Jakarta. Skripsi. Jakarta: Universitas Persada Indonesia Y.A.I.

Ardianto, Elvinaro dkk. 2007. Komunikasi Massa. Bandung: Simbiosa Rekatama Media

Ardianto, Elvinaro. 2001. Keterdedahan Tayangan Iklan Televisi Terhadap Kecenderungan Perilaku Konsumerisme Masyarakat Desa Di Kecamatan Rancaekek Kabupaten Bandung Jawa Barat. [Tesis]. Bogor (ID): Sekolah Pascasarjana, Institut Pertanian Bogor.

Asmira D. 2006. Keterdedahan iklan televisi dan perilaku khalayak (Kasus iklan produk mie instant di televisi pada dua komunitas urban dan semi urban di Kota Bogor). [tesis]. Bogor (ID): Institut Pertanian Bogor.

Astuti, Devi Tri. 1998. Hubungan antara Dukungan Sosial dan Harga Diri pada Anak yang Bekerja di Jalan di Jakarta. Skripsi. Depok: Universitas Indonesia.

Astuti, Devi Tri. 1998. Hubungan antara Dukungan Sosial dan Harga Diri pada Anak Yang Bekerja di Jalan di Jakarta. Skripsi. Depok: Universitas Indonesia.

Berg, Alan \& Muscat, Robert, J. 1987. Terj: Faktor Gizi. Bhratara Karya Aksara Jakarta 
Bovee, Courtland L., and William F. Arens, Contemporary Advertising, Illinois : Irwin Homewood, 1986

Bungin, Burhan. 2006. Sosiologi Komunikasi. Jakarta: Kencana

Bungin, Burhan. 2008. Sosiologi Komunikasi (Teori, Paradigma, dan Discourse Teknologi Komunikasi di Masyarakat). Jakarta: Kencana Prenada Media Group

Bungin, Burhan. 2011. Metodologi Penelitian Kuantitatif : Komunikasi, Ekonomi,

Burton, Graeme, "Membincangkan televisi “ sebuah pengantar kajian televisi” (Yogyakarta : Jalasutra, 2011), hal.116-117

Cholifatur R. 2015. Hubungan Antara Tingkat Pengetahuan dan Perilaku Anak Sekolah Dasar Mengenai Pemilihan Makanan Jajanan dengan Status Gizi di SD Negeri Kudu 02 Kecamatan Baki Kabupaten Sukoharjo. [Internet]. [Diunduh 18 November 2016]. Dapat diunduh di http://eprints.ums.ac.id/39816/13/NASKAH\% 20PUBLIKASI.pdf

Crain, W. 2009. Teori Perkembangan Manusia. Pustaka Pelajar. Yogyakarta. Edisi Bahasa Indonesia Pertama

dan Kebijakan Publik serta Ilmu-ilmu Sosial lainnya. Jakarta : Kencana

Dell, Hawkins, Roger J. Best, Kenneth A. Coney. 2001. Consumer Behavior Building Marketing Strategy 8th Edition, New Jersey: McGrawHill

Depdikbud. Kamus Besar Bahasa Indonesia, Jakarta: Balai Pustaka, 1996

Depdiknas, Kamus Besar Bahasa Indonesia, (Jakarta: Balai Pustaka, Edisi 3, 2003). (alMihrab, Rubrik : Telaah Utama, Edisi 16 Tahun ke-2, Semarang, 2005).

Desiarista, E dan Srirahayu Triastuti. 2011. Analisis Pengaruh Iklan, Kepercayaan Merk, dan Citra terhadap Minat Beli Konsumen. Jurnal Aset. [Internet]. [Diunduh 15 November 2016]. Volume 13 No 1. Dapat diunduh di http://jurnal.widyamanggala.ac.id/index.php/as etwm/article/view/22/18

Di Matteo, M. R. (1991). The Psychology of Health, Illness, and Medical care. Pasific Grove, California: Brooks / Cole Publishing Company.
Dian MK. 2010. Representasi Anak-Anak dalam Tayangan Iklan Komersial di Media. Jurnal Ilmiah Komunikasi "MAKNA". [Internet]. [Diunduh 24 Oktober 2016]. Vol. I No. 1. Dapat diunduh di http://download.portalgaruda.org/article.php?a $\underline{\text { rticle }=3750 \& \text { val }=309}$

Effendi, Onong Uchjana. 1993. Ilmu, Teori dan Filsafat Komunikasi. Bandung: PT. Citra Aditya Bakti.

Effendy, Onong Uchjana. (2007). Ilmu Komunikasi, Teori dan Praktek. Bandung: Remaja Rosdakarya

Eunike, Suci. 2009. Gambaran Perilaku Jajan Murid Sekolah Dasar di Jakarta. Jurnal Psikobuana. [Internet]. [Diunduh 17 November 2016]. Vol. 1, No1, Hal 29-38. Dapat diunduh di http://psikobuana.com/doc/29-38\%20\%20Jajan.pdf

Feberia P. 2010. Efek program siaran Bentang Parahyangan Bandung TV terhadap khalayaknya (kasus RW 04 Kelurahan Cigending, Kecamatan Ujungberung, Kota Bandung dan $R W 12$ Kelurahan Tamansari, Kecamatan Bandung Wetan, Kota Bandung) [skripsi]. Bogor (ID): Institut Pertanian Bogor

Febri, fatmalina. 2006. Penetuan Kombinasi Makanan Jajanan Tradisional Harapan Untuk Memenuhi Kecukupan Energi Dan Protein Anak Sekolah Dasar Di Kota Palembang. Tesis. Semarang: Gizi Masyarakat, UNDIP. Diunduh dari http://eprints.undip.ac.id pada tanggal 29 November 2016

Fitriyah, Neka. 2013. Iklan Televisi dan Perilaku Konsumtif Anak-Anak (Studi Kasus Pada Anak usia sekolah dasarN 13 Serang). Jakarta: Jurnal Al-Azhar Indonesia Seri Pranata Sosial. [internet]. [Diunduh 22 Oktober 2016]. Vol. 2, No 2, dapat di unduh dari: http://jurnal.uai.ac.id/index.php/SPS/article/d ownload/152/142

Gunarsa, S.D., \& Gunarsa, Y.S.D (2006). Psikologi Perkembangan Anak dan Remaja. Jakarta: PT BPK Gunung Mulia.

Gustam FW. 2014. Analisa Pengaruh Iklan Televisi Untuk Anak-Anak Terhadap Keputusan Pembelian Orang Tua. E-Journal Graduate Unpar Part A: Economics. [Internet]. [Diunduh 22 Oktober 2016]. Vol. 1, No. 2. Dapat diundug di 
http://journal.unpar.ac.id/index.php/unpargrad uate/article/view/871/1197

Hanggarawati, Utilithia Banguningsih. 2007. Hubungan antara Tingkat Stress dan Persepsi tentang Dukungan Sosial pada Remaja dengan Status Sosial Ekonomi (SSE) Rendah. Skripsi. Depok: Universitas Indonesia.

Hardiansyah dan Tambunan V. 2004. Angka Kecukupan Gizi Dalam Widyakarya Nasional Pngan dan Gizi VIII. LIPI. Jakarta

Hernawati, Riza dan Maya A.P. 2011. Televisi dalam Kehidupan Anak. Bandung.

Hurlock. 1999. Psikologi Perkembangan. Suatu Pendekatan Sepanjang Rentang Kehidupan, diterjemahkan oleh Istiwidayanti \& Soedjarwo. Jakarta: Erlangga

Jefkins, Frank F. 1982. Introduction to Marketing, Adsvertising and Public Relation, London : Macmillan Press

Kasali, Rhenald. 1995. Manajemen Periklanan Konsep dan Aplikasinya di Indonesia, Jakarta : PT Pusataka Utama Grafiti

Kementrian Komunikasi dan Informatika 2011. Laporan Tahunan Inspektorat Jendral Kemenkominfo 2011, Jakarta.

Lestari,I. 1996. Hubungan antara Harga Diri dan Interaksi Sosial dengan Perilaku Konsumtif Terhadap Produk Fashion pada Remaja. Skripsi. (Tidak Diterbitkan). Jogjakarta: Fakultas Psikologi Universitas Gajah Mada

Limandoko B. 2000. Desain komunikasi visual dan perilaku konsumen. Jurnal Nirmana [Internet]. [diunduh 21 Oktober 2013]. Vol. 02. No. 02. Tersedia pada: http://cpanel.petra.ac.id/ejournal/index.php/dk v/article/viewFile/16055/ 16047.

Maharani, Yuni. Pusat Tumbuh Kembang Anak. Jurnal Tingkat Sarjana Senirupa dan Desain. [internet]. [Diunduh 15 November 2016]. Dapat diunduh di https://www.google.co.id/url?sa=t\&rct=j\&q= \&esrc $=\mathrm{s} \&$ source $=$ web\&cd $=4 \&$ cad $=$ rja\&uact $=$ 8\&ved=0ahUKEwja_oC od3QAhVHs48KHZ a4DrwQFgg0MAM\&url=http $\% 3 \mathrm{~A} \% 2 \mathrm{~F} \% 2 \mathrm{Fju}$ rnal-

s1.fsrd.itb.ac.id $\% 2$ Findex.php $\% 2$ Finterior $\% 2 \mathrm{~F}$ article $\% 2 \mathrm{Fdownload} \% 2 \mathrm{~F} 42 \% 2 \mathrm{~F} 40$ \&usg $=\mathrm{AFQ}$ jCNEdOYpP6uSnzzVbYOiOWCTdQ0pR4g\& bvm=bv.139782543,d.c2I
Makmun (1995) Perkmbangan Anak. Bandung Remaja Rosdakarya

Maulin, Melly. 2013. “Sihir” Iklan Televisi dalam Menstimuli Perilaku Konsumtif Anak-anak. Jurnal Ilmu Politik dan Komunikasi. [Internet]. [ Diunduh 23 oktober 2016]. Vol. III No. 1. Dapat diunduh di http://jipsi.fisip.unikom.ac.id/_s/data/jurnal/vo lume-03/4-jipsi-unikom.pdf/pdf/4-jipsiunikom.pdf

Michelle V. 2013. Sikap Masyarakat Surabaya Mengenai Iklan Dancow Versi 'Dokter Kecil' di Televisi. Jurnal E-Komunikasi. [Internet]. [Diunduh 16 Desember 2016]. Dapat diunduh di

http://studentjournal.petra.ac.id/index.php/ilm u-komunikasi/article/viewFile/930/830

Moehji, Sjahmien. 1986. Ilmu Gizi. Jakarta: Bhrata Karya Aksara.

Nency, Y. \& Arifin, M.T. 2005. Gizi Buruk, Ancaman Generasi yang Hilang. Jurnal Inovasi Online Kesehatan, Vol.5, No.XVII

Notoatmodjo, s. 2003. Pendidikan dan perilaku kesehatan, Jakarta : PT Rineka Cipta

Notoatmodjo, s. 2005. Metodologi penelitian kesehatan. Jakarta : PT Rineka Cipta

Notoatmodjo, s .1993. Pengantar Kesehatan dan Ilmu Perilaku Kesehatan. Yogyakarta: Penerbit Andi Offset

Nuaraeni, Nani. 2008. Pengantar Periklanan

Prihatini, Ria. 2006. Hubungan Antara Kebiasaan Jajajn dan Pola Ativitas Fisik Serta FaktorFaktor lainnya dengan kejadian obesitas pada siswa-siswi sekolah dasar islam terpadu darul abidin depok tahun 2006. Skripsi. FKM UI

Purwaningwulan, M Maulin. (2013). Sihir Iklan dalam Menstimulasi Perilaku Konsumtif Anak-Anak. Jurnal Ilmu Politik dan Komunikasi. Vol. III No. 1 Hal. 63-70

Ridhoanova F. 2009. Hubungan antara keterdedahan iklan layanan masyarakat tentang pemilu presiden dan wakil presiden 2009 di televisi dengan sikap pemilih pemula di pedesaan [skripsi]. Bogor(ID). Institut Pertanian Bogor

Roscoe dikutip dari Uma Sekaran. 2006. Metoe Penelitian Bisnis. Jakarta : Salemba Empat. p :

Rossiter, John R., \& Larry Percy. (1987). Advertising and Promotion Management. New York : McGraw-Hill International Book C 
Safriana. 2012. Perilaku Memilih Jajanan Pada Siswa sekolah dasar di SDN. Garot Kecamtan darul imarah kabupaten aceh besar. [skripsi]. Depok (ID). Universitas Indonesia

Samsi SN. 2005. Hubungan keterdedahan siaran iklan produk susu bubuk balita di televisi dengan keputusan pembelian(kasus ibu rumah tangga di Perumahan Villa Bogor Indah, Bogor) [skripsi]. Bogor (ID). Institut Pertanian Bogor.

Sarafino, E. 1990. Health Psychology : Biopsychosocial Interactions. New York : John Wiley \& Sons

Setiawan, Edi.2010. Hati-Hati Jangan Jajan Sembarangan. Kementrian Kesehatan RI, Direktorat Jendral Bina Gizi dan KIA, yang diunduh melalui http://www.gizikia.depkes.go.id/archives/837

Silitonga RE. 2009. Perilaku menonton dan persepsi mahasiswa terhadap program jelajah di Trans TV (kasus mahasiswa Institut Pertanian Bogor pengikut mata kuliah komunikasi bisnis, semester genap tahun ajaran 2008/2009) [skripsi]. Bogor (ID). Institut Pertanian Bogor

Singarimbun, Masri dan Sofian Effendi, Metode Penelitian Survei, Jakarta: LP3ES, 2008

Smet, B. 1994. Psikologi Kesehatan. Jakarta : PT Grasindo

Suci. 2009. Gambaran Perilaku Jajan Murid Sekolah Dasar di Jakarta. Psikobuana. Diakses dari: http://www.psikobuana.com

Sudjiman, P. Dan Aart Van Zoest. 1996. Serba Serbi Semiotika. Jakarta: Gramedia Pustaka Utama

Suhartini. 2004. Perbedaan Proporsi Preferensi, Uang Saku, Pengetahuan Gizi Dan Sumber Informasi Dalam Menentukan Frekuensi Konsumsi Fast Food Pada Remaja SMA Negeri Di Kota Bogor, 2004 [Skripsi]. Depok: Fakultas Kesehatan Masyarakat, Universitas Indonesia

Sutisna RJ. 2000. Hubungan keterdedahan tayangan iklan di media televisi dengan perilaku konsumsi masyarakat Desa Kabupaten Bojonegoro Jawa Timur [tesis]. Bogor (ID). Institut Pertanian Bogor.

Tesis. Semarang. Gizi Masyarakat, UNDIP. Diunduh dari http://eprints.undip.ac.id

Wardiatmo. 1989. Makanan dalam Arti Sehat dan Sosial. Buletin Gizi 2 (13)
Widyatama, Rendra, PengantarPeriklanan, Pustaka Book Publisher, Yogyakarta, 2007.

Wiggins, B., Wiggins J. dan Zanden J. 1994. Social Psychology, the Fifth Edition. Mc.Graw-Hill, Inc.

Zastrow, Charles dan Karen K. Kirst-Ashman. 1987. Understanding Human Behavior and the Social Environment. Nelson-Hall Publisher.Chicago 